\title{
Investigation of the Effect of Using Activated Sludge Treated with Acetic Acid on Physical and Strength Properties of Recycled Pulp
}

\section{Istraživanje utjecaja uporabe aktivnog mulja tretiranog octenom kiselinom na fizička svojstva i čvrstoću reciklirane celuloze}

Preliminary paper • Prethodno priopćenje

Received-prispjelo: 26. 2. 2020.

Accepted-prihvaćeno: 26. 5. 2021.

UDK: $630 * 861.21 ; 630 * 862.31$

https://doi.org/10.5552/drvind.2021.2012

\author{
Licensee Faculty of Forestry and Wood Technology, University of Zarreb. \\ This article is an open access article distributed \\ under the terms and conditions of the \\ Creative Commons Attribution (CC BY) license.
}

\begin{abstract}
This study aimed to scrutinize chemical treatment of Mazandaran Wood and Paper mill activated sludge with $3 \%$ acetic acid for the manufacture of environmentally eco-friendly bio composite. In this study, the paper pulp required was obtained from the waste newsprint paper. The activated sludge was treated in a beaker for 3 min in $3 \%$ acetic acid and then in a water bath at 75 and $100{ }^{\circ} \mathrm{C}$ for 45 and 90 min. After that, the treated activated sludge was mixed and refined with waste newsprint paper pulp at ratios of $0,5,10,15$ and $20 \%$. The test specimens were prepared according to TAPPI standard and the physical properties (water absorption and porosity) and mechanical (tensile strength, tear strength, ring crush test, burst strength and folding strength) were measured. The results showed that the activated sludge treatment caused the increase in tear strength, ring crush test, burst strength and porosity as well as the decrease in water absorption, tensile strength and folding strength. FT-IR spectrum of the treated samples showed that the treatment with acetic acid strengthened and activated the functional groups on the surface of activated sludge fibers. The activated sludge added at a level of $5 \%$ at $100{ }^{\circ} \mathrm{C}$ for 90 min as well as at a level of $20 \%$ at $75^{\circ} \mathrm{C}$ for 45 min was more suitable than other treatments.
\end{abstract}

Keywords: activated sludge; acetic acid; newsprint paper; eco-friendly bio composite; resistance features

SAŽETAK • Cilj ovog rada bio je proučiti kemijsku obradu aktivnog mulja proizvedenog u tvornici drva i papira Mazandaran izvedenu 3 \%-tnom octenom kiselinom za proizvodnju ekološki prihvatljivog biokompozita. Celulozna kaša potrebna za istraživanje dobivena je od otpadnoga novinskog papira. Aktivni mulj obrađen je $3 \%$-tnom octenom kiselinom u čaši, i to u trajanju 3 minute, a zatim u vodenoj kupelji temperature 75 i $100^{\circ} \mathrm{C}$ u trajanju od 45 i 90 min. Nakon toga taj je aktivni mulj pomiješan i rafiniran s celuloznom kašom od otpadnoga novinskog papira u omjerima od 0, 5, 10, 15 i 20\%. Ispitni su uzorci pripremljeni prema TAPPI normi, nakon čega su izmjerena njihova fizička svojstva (upijanje vode i poroznost) te mehanička svojstva (vlačna čvrstoća, čvrstoća na kidanje, tlačna čvrstoća prstena, čvrstoća na pucanje i preklopna čvrstoća). Rezultati su pokazali da je kemijska obrada aktivnog mulja pridonijela povećanju čvrstoće uzoraka na kidanje, otpornosti na tlačnu silu, čvrstoći na pucanje i poroznost te smanjenju upijanja vode, kao i vlačne i preklopne čvrstoće. FT-IR spektri tretiranih uzoraka poka-

\footnotetext{
Authors is PhD Student at Islamic Azad University, Chalous branch, Department of Wood Science and Paper Technology, Chalous, Iran.

${ }^{2}$ Authors are researchers at Islamic Azad University, Chalous branch, Department of Wood Science and Paper Technology, Chalous, Iran.
} 
zali su da obrada octenom kiselinom ojačava i aktivira funkcionalne skupine na površini vlakana aktivnog mulja. Aktivni mulj dodan u omjeru od $5 \%$ pri $100{ }^{\circ} \mathrm{C}$ i u trajanju 90 minuta te u omjeru od $20 \%$ pri $75{ }^{\circ} \mathrm{C}$ i tijekom 45 minuta bio je prikladniji od ostalih uzoraka.

Ključne riječi: aktivni mulj; octena kiselina; novinski papir; ekološki prihvatljiv biokompozit; otpornost

\section{INTRODUCTION}

\section{UVOD}

Today, population growth and rising living standards, paper consumption and production, as well as production of other industrial and agricultural products have risen and as a result, the amount and variety of solid waste produced has increased. Therefore, environmental pollution from agricultural and industrial waste is a global concern and safe management of hazardous waste will be one of the greatest challenges facing humanity. Therefore, finding a suitable social, technical, economic and environmental solution to have a greener and cleaner environment is a global concern. Several countries are trying to solve this problem by recycling waste (Lertsutthiwong et al., 2008; Pappu et al., 2007). Mazandaran Wood and Paper Industries Complex annually produce 75000 tons, 52000 tons, 38000 tons of fluting paper, newsprint and printing and writing paper, respectively. In addition, solid waste, paper mill sludge, waste from the pulp and paper process or paper recycling due to the large amounts produced leads to a lot of pressure on the environment at the paper mills. Some paper mills burn sludge to decrease the produced sludge volume, although the space required for this operation is rare and expensive. The paper mill sludge also contains $45-55 \%$ moisture and $20 \%$ solids, which causes problems for transport. The landfill of paper mill waste, in addition to not being economical, causes environmental issues and groundwater pollution. On the other hand, a large area of land is required for the landfill of fibers (Horace et al., 1999; Smook, 1995). On average, sludge production (organic and inorganic) in the wood and paper mill of Mazandaran is 1700 tons per month. In addition, sludge dry percentage is about $25 \%$ (along with the moisture), so the dry sludge produced per month and day are about 425 and 4 tons, respectively. Semi-dry activated sludge contains organic and inorganic substances such as sodium, sulfur, extractives, fats, waxes, sterols, and fiber fines, and calcium carbonate (due to filler) along with the tree bark. Moreover, active sludge contains hazardous chemical compounds that can decrease the amount of harmful chemical compounds by chemical treatment (Son et al., 2001)

Ghasht Roodkhani et al. (2010) reported that the values of tensile, tear, burs, folding strength, and density of the mixed papers compared to the control sample decreased, while the values of bulk, thickness, brightness, and opacity increased. Nazeri et al. (2008) showed that the increase in CMP (Chemical Mechanical Pulp) fine amount leads to increase the air resistance and opacity and also decrease roughness, so variations in CMP fines have no effect on brightness. Tudarvari et al. (2016) examined the effect of fiber length variations of different OCC (Old Corrugated Container) pulp-recycled papers on strength properties. The results showed that OCC pulp produced from different paper sources have different fiber length distribution that has a significant impact on the fluting paper strength properties. The OCC pulp with higher amounts of long fiber and lower amounts of fines has good strength properties (tensile strength, burst strength, and tear strength) for producing fluting paper. Girones et al. (2010) stated that increasing the amount of sludge in composites will result in a composite with lower tensile strength. Therefore, in composites that are exposed to tensile force, the paper mill sludge acts as a filler, and when the material is subjected to bending force, the sludge acts somewhat like a reinforcement. Ismail and Bakar (2004) reported that increasing the amount of paper sludge in composites increases water absorption and decreases tensile strength. Ismail and Bakar (2005) reported that the ester treatment and acetylation of the sludge of the paper mill in the manufacture of composites improves the tensile strength and Young's modulus and also reduces water absorption.

The aim of this research is to use activated sludge as an additive with different ratios and also to use modified activated sludge with acetic acid to improve the physical-mechanical properties of paper produced from recycled fibers and activated sludge.

\section{MATERIALS AND METHODS}

\section{MATERIJALI I METODE}

\subsection{Sample preparation \\ 2.1. Priprema uzoraka}

In this study, $10 \mathrm{~kg}$ of waste newspaper with dimensions of $5 \mathrm{~cm} \times 5 \mathrm{~cm}$ was prepared by hand. The newspaper pieces were kept in water for 24 hours and then converted into a pulp in a disintegrator (British Pulp Evaluation Apparatus manufactured by Mavis Engineering Ltd.London N.1. England) at $300 \mathrm{rpm}$ for $30 \mathrm{~min}$. In addition, the waste dry sludge was prepared from Mazandaran wood and paper mill located in the Sari's Pahne Kola and transferred to the laboratory, and then about $2 \mathrm{~kg}$ was soaked in water for 24 hours. After that, both materials were mixed by the disintegrator at around $300 \mathrm{rpm}$. Then, the newspaper paste was dewatered with 40-mesh and sludge with 200-mesh. The waste newspaper paste and activated sludge were calculated and mixed in the amount required for the experiment (handsheet) according to Table 1 . The waste newsprint pulp and activated sludge were refined using a refinery PFI (No. 221; Beating Performance Adjusted by the Norwegian Pulp and Paper Research Institute, Trondheim, Norway) at $300 \mathrm{rpm}$. Then, the water was added to the mixture obtained up to a volume of 10 liters. Furthermore, about $300 \mathrm{cc}$ of the obtained solu- 
Table 1 Percentage of activated sludge and waste newsprint pulp

Tablica 1. Postotni udio aktivnog mulja i celulozne kaše od otpadnoga novinskog papira

\begin{tabular}{|c|c|c|}
\hline $\begin{array}{c}\text { Test } \\
\text { samples } \\
\text { Ispitni } \\
\text { uzorci }\end{array}$ & $\begin{array}{c}\text { Activated sludge, \% } \\
\text { (Treated } \\
\text { Aktivni mulj, } \% \\
\text { (tretirani** } \text { i netretirani) }^{*} \text { ) }\end{array}$ & $\begin{array}{c}\text { Waste newspa- } \\
\text { per pulp } \\
\text { Celulozna kaša } \\
\text { od otpadnoga } \\
\text { novinskog papira }\end{array}$ \\
\hline $\begin{array}{c}\text { Control/ } \\
\text { Kontrolni } \\
\text { uzorci }\end{array}$ & 0 & 100 \\
\hline 1 & 5 & 95 \\
\hline 2 & 10 & 90 \\
\hline 3 & 15 & 85 \\
\hline 4 & 20 & 80 \\
\hline
\end{tabular}

**Treated in a bain-marie (warm water bath) at different temperatures and times $\left(75,100{ }^{\circ} \mathrm{C}\right.$ and $\left.45,90 \mathrm{~min}\right) /$ tretiran metodom bainmarie (kupelj s toplom vodom) pri različitim temperaturama i uz različita vremena trajanja $\left(75\right.$ i $100{ }^{\circ} \mathrm{C}$ te 45,90 minuta)

tion was removed/isolated for weight control. Then, the test samples of the waste newsprint pulp with 100 , 95, 90, 85 and $80 \%$ ratios and untreated activated sludge in 5 levels $(0,5,10,15,20 \%)$ according to the TAPPI T205 sp-12 (2015) with a basis weight of $120 \mathrm{~g} /$ $\mathrm{m}^{2}$ were prepared. The thickness of the handmade specimens was measured using a thickness gauge (E.J.CADY \& CO. CHICAGO, USA) to the nearest 0.001 millimeter.

\subsection{Chemical treatment of activated sludge}

2.2. Kemijska obrada aktivnog mulja

To improve the mixing conditions with newspaper, paste and activated sludge, sludge samples with the ratios listed in Table 1 were placed separately in beakers containing $3 \%$ acetic acid for $30 \mathrm{~min}$. Then, they were treated in a Bain Marie bath $(45,90$ min and $\left.75,100^{\circ} \mathrm{C}\right)$. Test specimens were prepared and pressed according to TAPPI T205 sp-12 (2015) standard with a base weight of $120 \mathrm{~g} / \mathrm{m}^{2}$ and then dried. Finally, the strength and water absorption properties of handsheets were measured.

\subsection{Mechanical and physical properties of} handsheets

2.3. Mehanička i fizička svojstva laboratorijskih listova papira

The properties of 210 handsheets were calculated. Tensile strength, burst resistance, tear strength, ring crush test (RCT), and water absorption indices were used in accordance with TAPPI T494 om-13 (2015),
TAPPI T403 om-10 (2015), and TAPPI T496 sp(2015) standards, TAPPI T818 cm-07 (2015) and TAPPI T441 om-13 (2015), respectively.

2.4 Attenuated total reflection (ATR) spectroscopy 2.4. Pojačana infracrvena spektroskopija (ATR)

ATR spectroscopy was used to determine the status of the active groups present in the handheld samples made from untreated and acetic acid-treated paper paste and sludge. For this purpose, the JASCO FTIR4700 device made in Japan (Japan Spectroscopic CO., LTD. Hachioji city Tokio Japan) was used.

\subsection{Statistical analysis \\ 2.5. Statistička analiza}

In this study, the effect of activated sludge on physical and strength properties of recycled pulp obtained by mixing activated sludge and newspaper wastepaper was statistically evaluated. Statistical analysis was performed using SPSS software (IBM Corporation, v.23, Armonk, NY, USA) in the form of one-way analysis of variance. Finally, the means were grouped using Duncan's test at a confidence level of $5 \%$.

\section{RESULTS AND DISCUSSION} 3. REZULTATI I RASPRAVA

The results of statistical analysis showed that there was a significant difference in the physical and mechanical properties of the handsheets from activated sludge treated with acetic acid (at different temperatures and times) and untreated at the $5 \%$ level (Table 2).

\subsection{Comparison of FT-IR spectra of activated} sludge samples

3.1. Usporedba FT-IR spektara uzoraka aktivnog mulja

FT-IR spectra of control, untreated and acetic acid-treated sludge are presented in Figure 1. The parts of the spectra with the wavenumber between 2700 and $3700 \mathrm{~cm}^{-1}$ and 2100 and $2500 \mathrm{~cm}^{-1}$ are shown separately.

\subsection{Tear strength \\ 3.2. Čvrstoća na kidanje}

The average thickness of the handsheets was about $300 \mu \mathrm{m}(0.3 \mathrm{~mm})$. The results of analysis of variance showed that there was a significant difference in the strength properties of the paper samples $(p<0.05)$. The results showed that by increasing activated sludge, the tear strength in the paper made decreased. Since the

Table 2 One-way ANOVA properties of activated sludge treated with acetic acid

Tablica 2. Svojstva jednosmjerne analize varijance aktivnog mulja tretiranoga octenom kiselinom

\begin{tabular}{|c|c|c|c|c|c|c|c|c|c|c|c|c|c|c|}
\hline $\begin{array}{l}\text { Characteristic } \\
\text { variable } \\
\text { Karakteristična } \\
\text { varijabla }\end{array}$ & \multicolumn{2}{|c|}{ RCT } & \multicolumn{2}{|c|}{$\begin{array}{c}\text { Water } \\
\text { absorption } \\
\text { (Cobb 60) } \\
\text { Upijanje vode } \\
\text { (Cobb 60) }\end{array}$} & \multicolumn{2}{|c|}{$\begin{array}{l}\text { Tear strength } \\
\text { Čvrstoća na } \\
\text { kidanje }\end{array}$} & \multicolumn{2}{|c|}{$\begin{array}{c}\text { Tensile } \\
\text { strength } \\
\text { Vlačna čvrstoća }\end{array}$} & \multicolumn{2}{|c|}{$\begin{array}{l}\text { Burst strength } \\
\text { Čvrstoća na } \\
\text { pucanje }\end{array}$} & \multicolumn{2}{|c|}{$\begin{array}{l}\text { Folding } \\
\text { strength } \\
\text { Preklopna } \\
\text { čvrstoća }\end{array}$} & \multicolumn{2}{|c|}{$\begin{array}{l}\text { Porosity } \\
\text { Poroznost }\end{array}$} \\
\hline Treatments & $F$ & Sig.* & $F$ & Sig. & $F$ & Sig. & $F$ & Sig. & $F$ & Sig. & $F$ & Sig. & $F$ & Sig. \\
\hline Vrsta obrade & 18.151 & 0.0001 & 132.717 & 0.0001 & 16.092 & 0.0001 & 14.617 & 0.0001 & 8.746 & 0.0001 & 6.779 & 0.0001 & 35.228 & 0.0001 \\
\hline
\end{tabular}

* Sig. - significant / značajno 


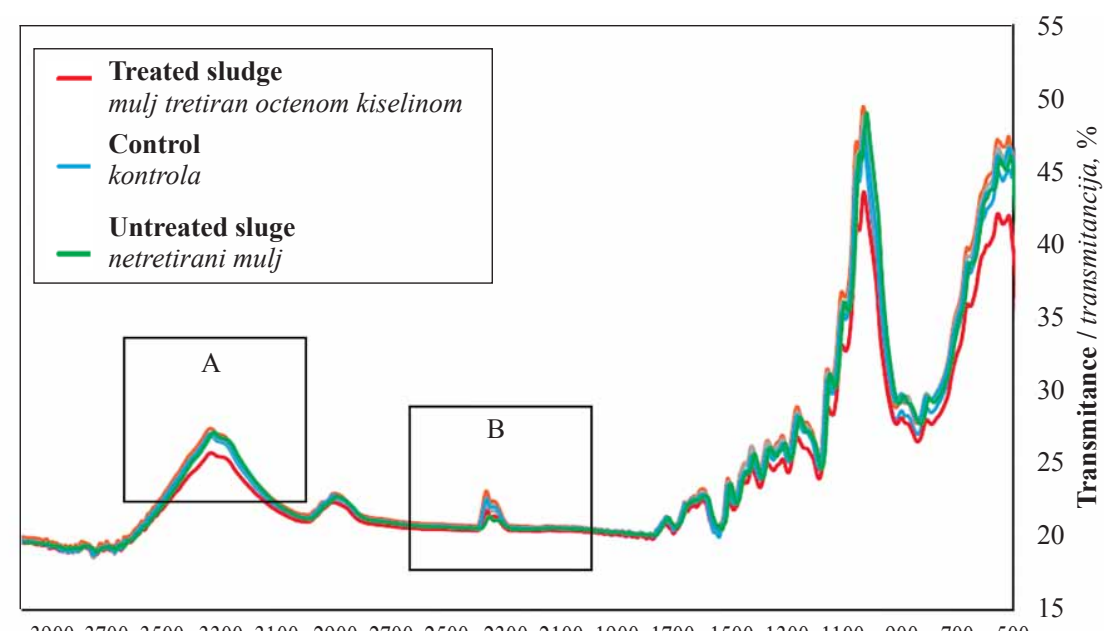

$390037003500330031002900270025002300210019001700150013001100 \quad 900 \quad 700 \quad 500$

Wavenumber / valni broj, $\mathrm{cm}^{-1}$

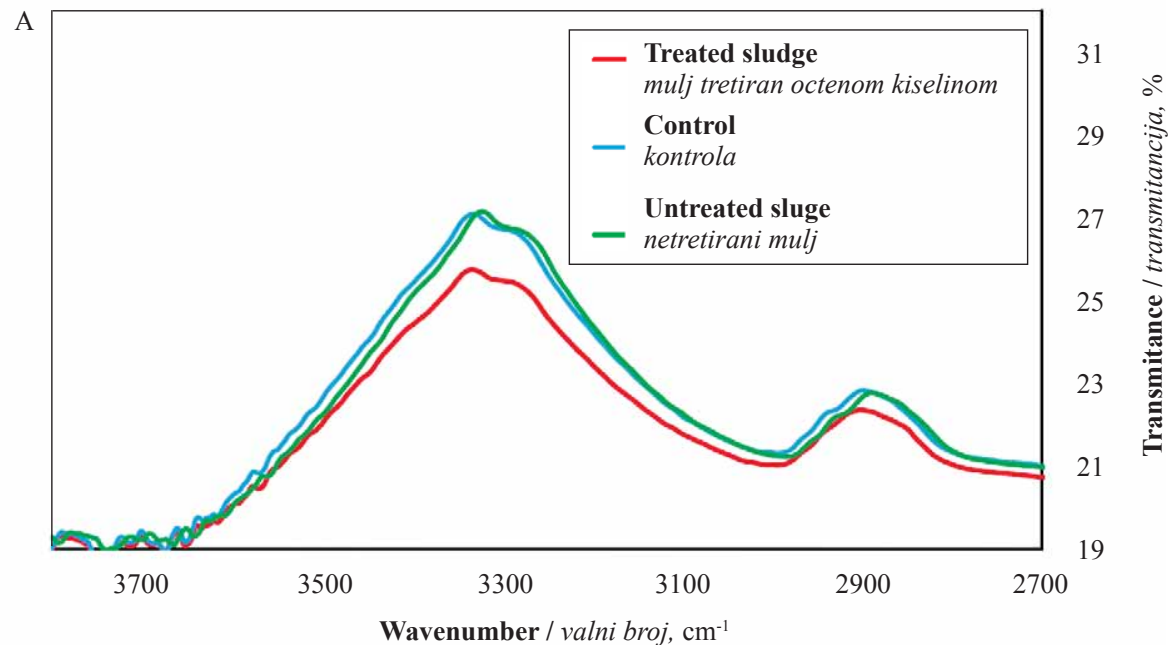

B

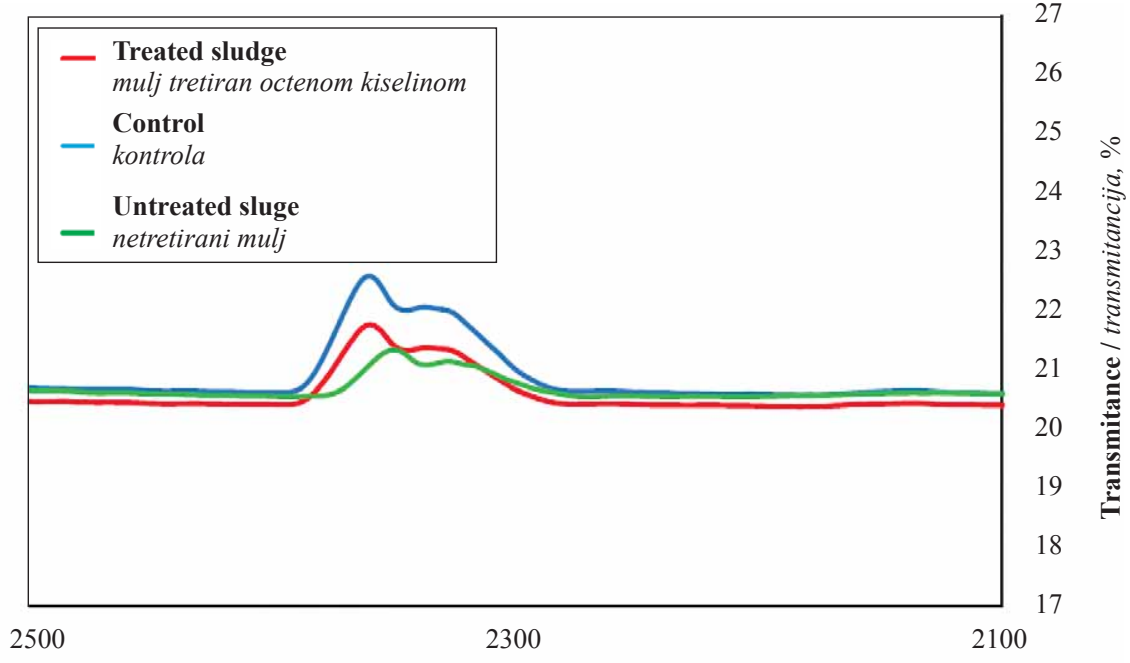

Wavenumber / valni broj, $\mathrm{cm}^{-1}$

Figure 1 FT-IR spectra of control, untreated and acetic acid-treated sludge

Slika 1. TGA FT-IR spektri kontrolnoga i netretiranog mulja te mulja tretiranoga octenom kiselinom 


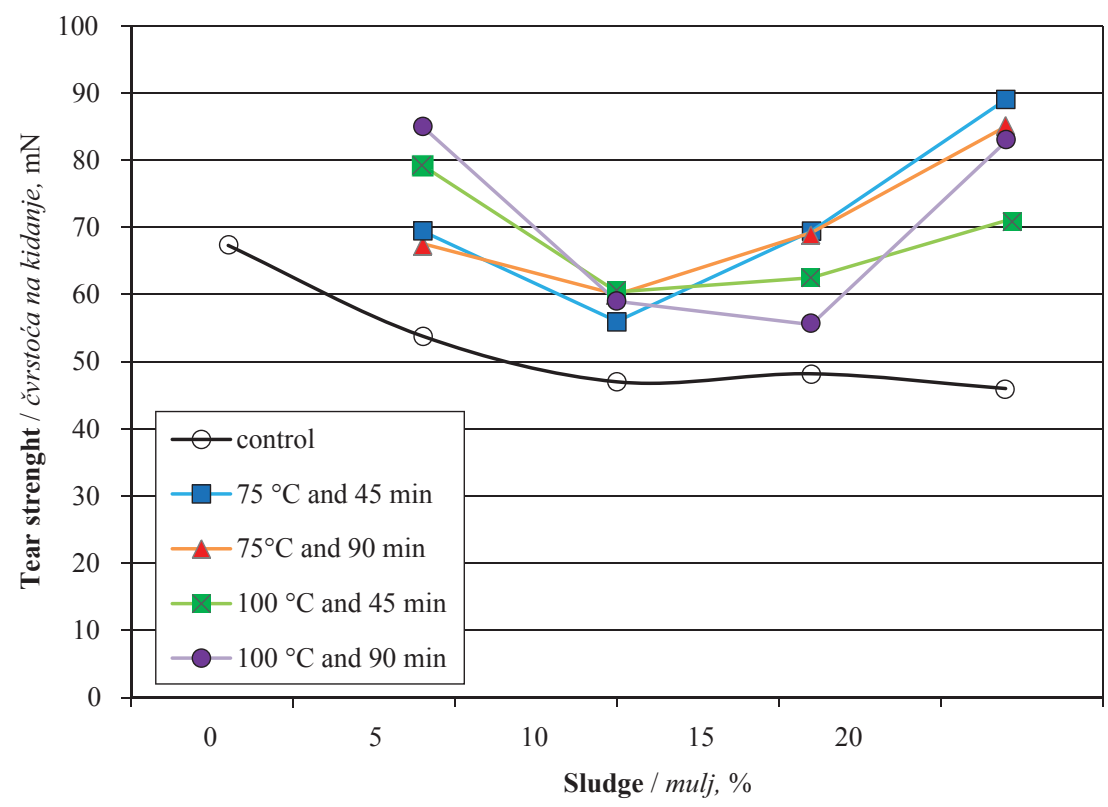

Figure 2 Comparison of tear strength of samples made by adding activated sludge to waste newsprint paper Slika 2. Usporedba čvrstoće na kidanje uzoraka napravljenih dodavanjem aktivnog mulja otpadnome novinskom papiru

fiber length, the linear density of fibers and fines in activated sludge are lower than in the waste newsprint paper components, the addition of untreated activated sludge to the samples decreased the tear strength. Comparing the spectrum of untreated activated sludge and control, the attenuation of the peak related to hydroxyl groups is visible, which indicates less resistance of paper made with untreated activated sludge. Significant changes after modification in different bands are attributed to different components, which include cellulose, hemicellulose, and lignin. The decrease in spectrum intensity at $3300 \mathrm{~cm}^{-1}$ wavelength due to treatment can be attributed to hydroxyl $(\mathrm{OH})$ groups (Sabazoodkhiz et al., 2017). The hydroxyl tensile region is of particular importance for explaining hydrogen bonding patterns (Clausen et al., 2010) (Figure 1). Bagherzadeh et al. (2013) stated that the decrease in strength is impaired by increasing the filler surface area, because the filler materials in the paper act as a separator, reducing the fiber connections and thus reducing the tear strength. (Bagherzadeh, 2013). Barzan et al. (2015) also reported that, compared to control treatment paper, handmade papers filled with extracted calcium carbonate reduced tear resistance by approximately $19 \%$.

The activated sludge treated with $3 \%$ acetic acid significantly increased the tear strength. The acetic acid treatment can indicate the improvement of fiber surface and better paper formation, and provides a more suitable substrate for the physical and mechanical properties of paper. The most suitable treatment results, with the highest tear strength, were achieved with the samples treated with acetic acid at $75^{\circ} \mathrm{C}$ for $45 \mathrm{~min}$. The results showed that by adding the treated activated-sludge (acetic acid) to the untreated samples with a ratio of 5 to $20 \%$, the tear strength initially de- creased and then showed a significant increase of up to $20 \%$. Moreover, a mixing ratio of 5 and $20 \%$ of the treated activated-sludge (with acetic acid) was always more tear resistant than the control sample. And also, by adding $5 \%$ (at $100{ }^{\circ} \mathrm{C}$ for $90 \mathrm{~min}$ ) and $20 \%$ (at 75 ${ }^{\circ} \mathrm{C}$ for $45 \mathrm{~min}$ ) of the treated activated sludge, the most suitable tear strength was observed. Additionally, the absorption peak intensity of $1791 \mathrm{~cm}^{-1}$ in the treated samples was less than $1544 \mathrm{~cm}^{-1}$, which indicates the presence of a reaction between acidic groups in acetic acid and hydroxyl groups in wood paste, which creates a high-intensity ester functional group. (Neeru et al., 2013) (Figure 1).

\subsection{Tensile strength \\ 3.3. Vlačna čvrstoća}

The results showed that the increasing activated sludge increased the tensile strength of the resulting paper. Due to the low fiber lengths and fines in activated sludge and also higher specific surface, the addition of untreated activated sludge to the specimens increased the specific surface and tensile strength of the test specimens. The tensile strength index of the samples can be seen in Figure 3. Tensile strength is one of the most important strengths of the paper that protects it against tensile stresses. Paper weight, fiber roughness, and fiber width are the factors affecting tensile strength. Tensile strength increases with increasing fiber length, increasing refining intensity and press pressure, and performing surface sizing on paper (Scott, 2007). The results showed that the tensile strength index increased by adding untreated activated sludge to the recycled fiber pulp. It appears that the reason of this increase can be attributed to the high specific surface area of the activated sludge (Nazeri et al., 2008). Primary and secondary materials improve the 


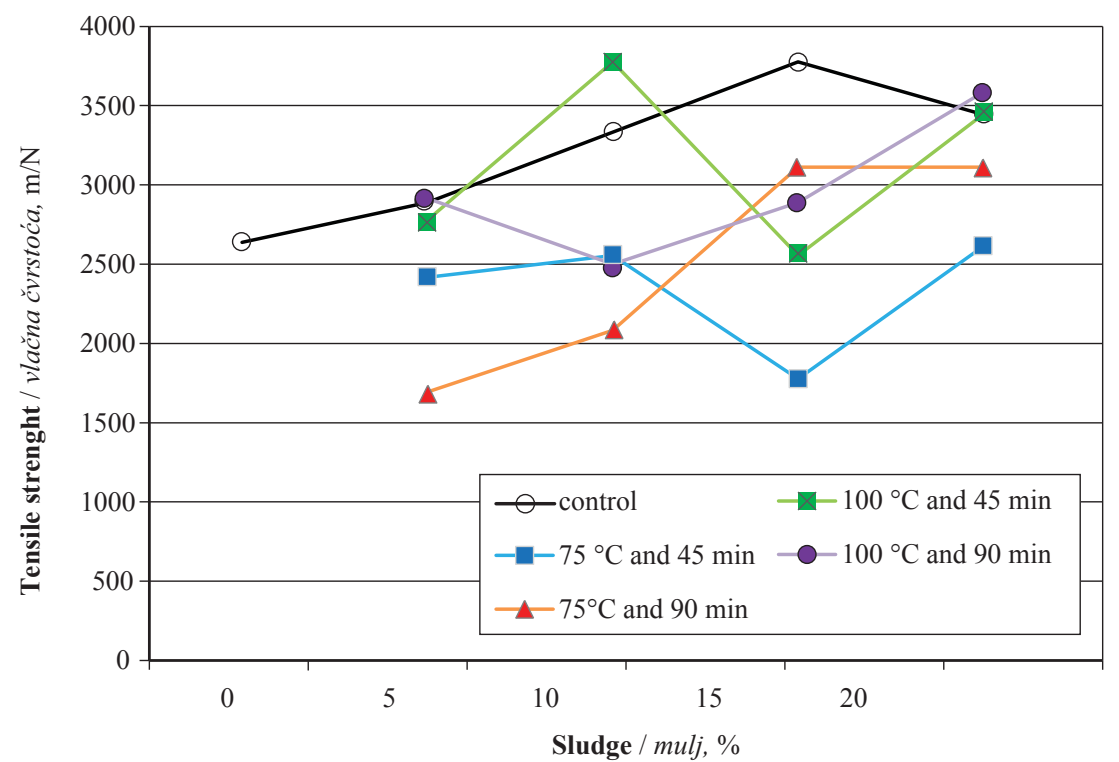

Figure 3 Comparison of tensile strength of samples made by adding activated sludge to waste newsprint paper Slika 3. Usporedba vlačne čvrstoće uzoraka napravljenih dodavanjem aktivnog mulja otpadnome novinskom papiru

strength properties of the paper (Krogerus et al., 2002). Son et al. (2004) showed that the swelling and tensile properties of the composites improved slightly with the addition of paper sludge compared to the control samples (Son et al., 2004). Additionally, activated sludge treated with $3 \%$ acetic acid resulted in a slight decrease in the tensile strength of some of the treated samples. Among the treatments, the most appropriate treatment and the highest tensile strength were observed in samples treated with acetic acid at $100{ }^{\circ} \mathrm{C}$ for $45 \mathrm{~min}$ with a mixing ratio of $10 \%$, at $100{ }^{\circ} \mathrm{C}$ for $90 \mathrm{~min}$ with a mixing ratio of $20 \%$, at $75^{\circ} \mathrm{C}$ for 90 min with a mixing ratio of $15 \%$, and $15 \%$ in the control sample. In contrast, the results of other studies have shown that the treatment of esterification and acetylation improved the tensile strength and length change in the fracture zone as well as the Young's modulus in composites and reduced water absorption (Ismail and Bakar, 2005).

The removal of the corresponding peak in the adsorption region of $1248.34 \mathrm{~cm}^{-1}$ in activated sludge can be due to the flexural vibrations of phenolic hydroxyl. Additionally, the removal of peaks in the adsorption zones of $1237.03 \mathrm{~cm}^{-1}$ is closely related to the $\mathrm{C}=\mathrm{O}, \mathrm{C}=\mathrm{C}$, and $\mathrm{C}=\mathrm{O}$ bonds of the carbonyl units, and the adsorption region of $1412.12 \mathrm{~cm}^{-1}$ is related to aromatic $\mathrm{C}-\mathrm{H}$ and $\mathrm{C}-\mathrm{H}$ associated with type II alcohols; $\mathrm{C}=\mathrm{O}$ is also treated in activated sludge and attenuates or removes carbonyl groups (Figure 1) (Mehmood et al., 2019).

\subsection{Ring crush test (RCT)}

\subsection{Otpornost na tlačnu silu}

The results showed that, by increasing activated sludge, the ring crush of the resulting samples decreased. Since the lengths and fines of fibers in activated sludge are shorter than in waste newsprint paper components, the addition of untreated activated sludge to the specimens causes the short fibers and some components of fine sludge to be placed in the $\mathrm{Z}$ direction of the treated specimens, which will decrease the ring crush. Activated-sludge treated with $3 \%$ acetic acid decreased in some treatments and slightly increased in ring crush test. Among the treatments, the best treatment and the highest ring crush test in the acetic-acid treated samples were at $100{ }^{\circ} \mathrm{C}$ for $90 \mathrm{~min}$ (Figure 4). The results showed that the addition of 5 to $20 \%$ activated-sludge treated with acetic acid to the untreated samples resulted in a significant increase in the ring crush. In addition, the mixing of $15 \%$ and $20 \%$ of activated sludge treated with acetic acid consistently showed the highest increase in ring crush than the control sample. The data analysis illustrated that there is a significant difference between the mean ring crush tests of treatments at the $1 \%$ level.

\subsection{Burst strength}

3.5. Čvrstoća na pucanje

The results showed that, by increasing the activated sludge, the resistance to bursting of the made samples decreased. This can be due to the presence of more fillers between the fibers, such as calcium carbonate (polymorphism of calcite), and the small particle size of calcium carbonate fillers in untreated activated sludge, which reduces the level of bonds. In contrast, the addition of activated sludge and weakening of the bond between the fibers reduces the mechanical strength (Akbari et al., 2017). Additionally, it seems that the short length of fibers in activated sludge and the use of recycled fibers can be another reason to reduce the mechanical properties (Miri et al., 2016). Additionally, except in samples treated with $3 \%$ acetic acid activated-sludge at $100{ }^{\circ} \mathrm{C}$ for $90 \mathrm{~min}$, the resistance to bursting decreased slightly in other treatments (Figure 5). The results showed that by adding 5 to $20 \%$ of acetic-acid treated activated-sludge to the untreated samples, the resistance to bursting of the samples increased markedly up to $20 \%$. The burst strength of the sample from the mixing of 15 to $20 \%$ showed a significant increase as well. The best tensile strength in 


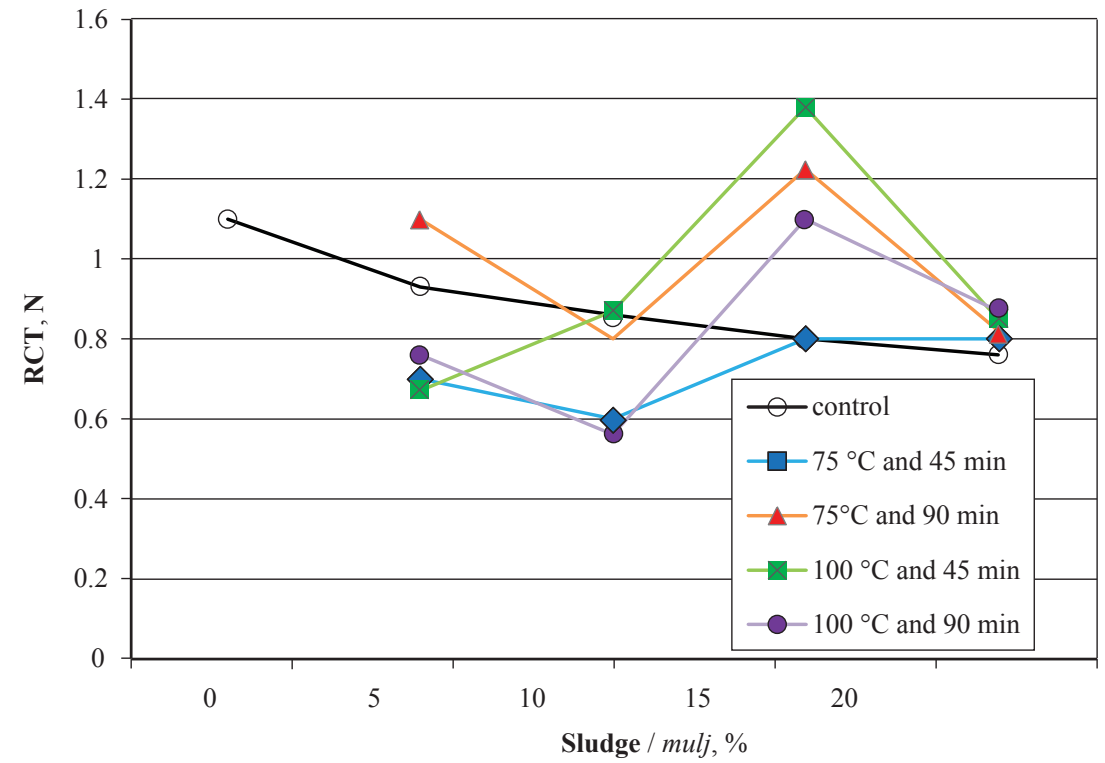

Figure 4 Comparison of ring crush test of samples made by adding activated sludge to waste newsprint paper

Slika 4. Usporedba otpornosti na tlačnu silu uzoraka napravljenih dodavanjem aktivnog mulja otpadnome novinskom papiru

samples treated with acetic acid was at $100^{\circ} \mathrm{C}$ for 90 and $45 \mathrm{~min}$. Hemicellulose and lignin are affected by the treatments, which reduces the amount of hydroxyl groups and has a significant effect on lignin (Mehmood et al., 2019). Aliphatic is seen in the absorption range of $3312 \mathrm{~cm}^{-1}$ (Figure 1).

\subsection{Water absorption (Cobb 60)}

3.6. Upijanje vode (Cobb 60)

The results of analysis of variance showed that there was a significant difference in the physical prop- erties (water absorption) of the made paper samples ( $\mathrm{p}$ $<0.05$ ). The results showed that, by increasing the activated sludge, the water absorption percentage of the samples made increased. Since the fines and specific surface of the activated sludge are higher than those of waste newsprint paper components, the addition of untreated activated-sludge to the samples increased the water absorption of the samples (Figure 6). Therefore, hydrophilic structures in activated sludge as well as moisture absorption by recycled newspaper fibers can be a reason to reduce the strength properties and in-

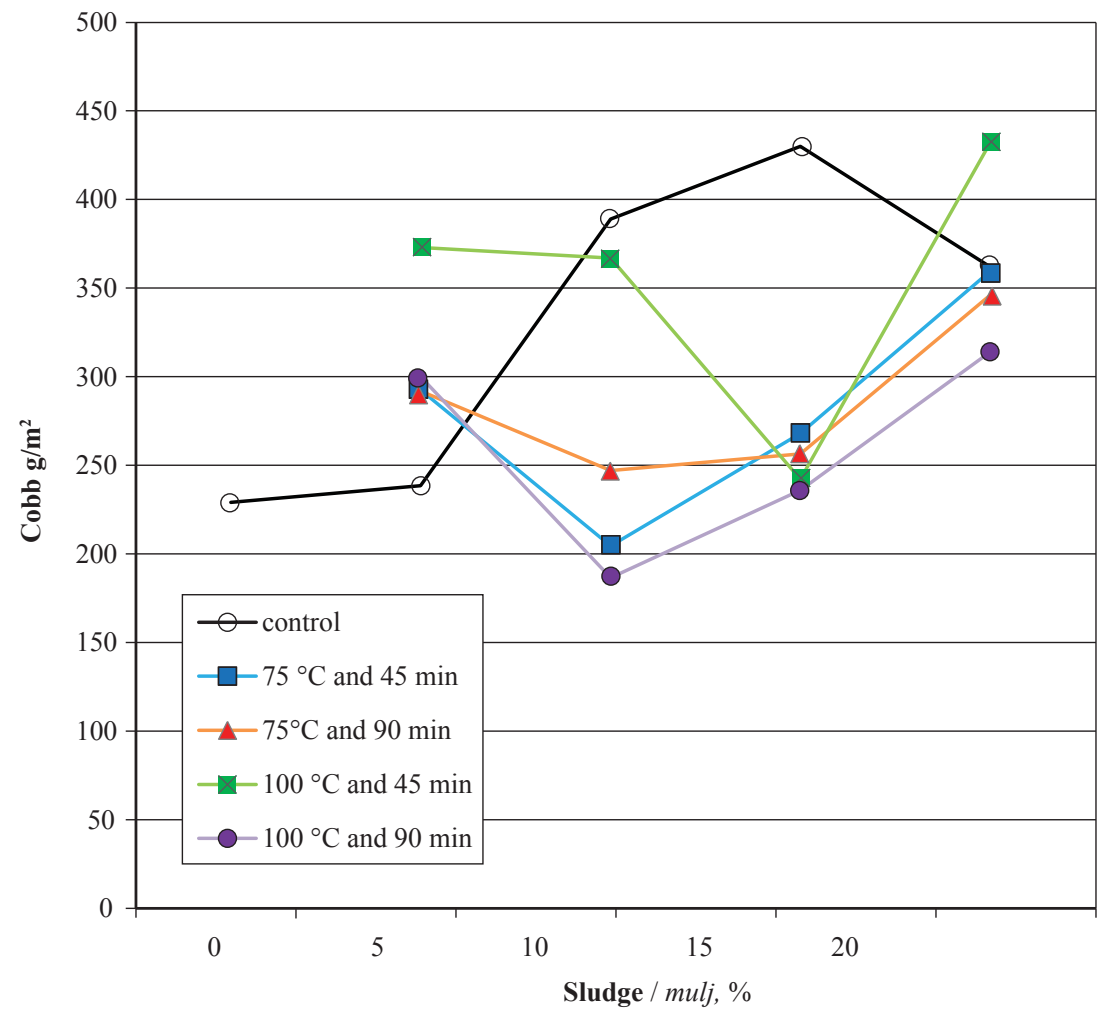

Figure 5 Comparison of burst strength of samples made by adding activated sludge to waste newsprint paper Slika 5. Usporedba čvrstoće na pucanje uzoraka napravljenih dodavanjem aktivnog mulja otpadnome novinskom papiru 


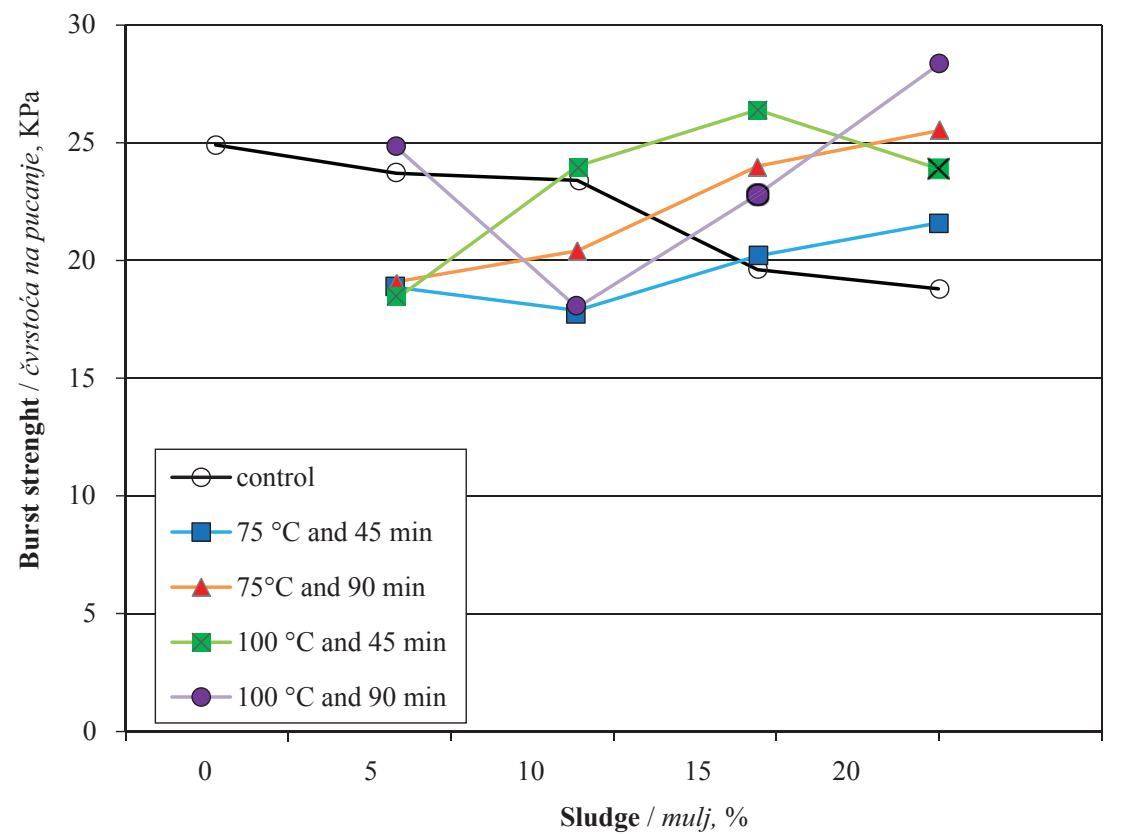

Figure 6 Comparison of burst strength of samples made by adding activated sludge to waste newsprint paper

Slika 6. Usporedba čvrstoće na pucanje uzoraka napravljenih dodavanjem aktivnog mulja otpadnome novinskom papiru

crease water absorption. The chemical treatment of activated sludge with $3 \%$ acetic acid showed a significant increase in water absorption of the samples. Moreover, among the treatments, the highest water absorption was observed in samples treated with acetic acid at $100{ }^{\circ} \mathrm{C}$ for $45 \mathrm{~min}$. The results showed that, by adding 5 to $20 \%$ of the activated sludge treated with acetic-acid to the untreated samples, the water absorption of the samples was firstly decreased and then significantly increased up to $20 \%$. The water absorption in the treated samples with mixing ratios was always lower than the control samples. The lowest and the best water absorption was observed in samples treated with acetic acid at $100{ }^{\circ} \mathrm{C}$ for $90 \mathrm{~min}$. Additionally, the region of the $2300 \mathrm{~cm}^{-1}$ peak belonged to the carbonyl groups, which indicates hemicellulose leaching (Pandey et al., 2012) (Figure 1). Ismail and Bakar (2004) reported that increasing the amount of paper sludge in composites increased the Young's modulus and water absorption.

\section{CONCLUSIONS}

4. ZAKLJUČAK

The main purpose of this study was to improve the physical and mechanical properties of paper made from activated sludge and recycled fibers by acetic acid treatment.

The addition of the untreated activated-sludge of the paper mill to the waste newsprint paper decreased some mechanical resistances up to $20 \%$ and increased tensile strength up to $27 \%$; it also increased the physical properties such as the water absorption up to $55 \%$ and porosity of the specimens up to $4 \%$.

The addition of the activated-sludge treated with $3 \%$ acetic acid to the waste newsprint paper increased the maximum mechanical strength up to $35 \%$ and de- creased the water absorption by up to $50 \%$ and the tensile strength up to $20 \%$. In addition, a significant increase in tear strength and ring crush test, as well as a decrease in water absorption, are important features for the specimens made.

The best mixing ratio for the specimens made included activated-sludge treated with $3 \%$ acetic acid in a mixing ratio of 5 and $20 \%$ with the waste newspaper at 100 and $75{ }^{\circ} \mathrm{C}$ for 90 and $45 \mathrm{~min}$, respectively, and especially $75^{\circ} \mathrm{C}$ for $45 \mathrm{~min}$.

\section{REFERENCES}

\section{LITERATURA}

1. Akbari, M.; Asadpur, G.; Nazarnezhad, N., 2017: The effect of using calcium carbonate from water treatment on the strength properties of congress paper prepared from OCC and NSSC pulp. Iranian Journal of Wood and Paper Science Research, 32 (1): 118-130. (in Persian). https://doi: 10.22092/IJWPR.2017.107128.

2. Bagherzadeh, F., 2013: Determining the Optimal Consumption of Fillers (China Clay and GCC) in the Fluting Papers that Produced from Mixture of NSSC and OCC Pulps with Maintaining Strength Properties. Master's Thesis, University of Sari Agriculture and Natural Resources, Mazandaran, Iran (in Persian).

3. Barzan, A.; Resalaty, H.; Atoei, G. A., 2015: Study of using water softening process byproduct, calcium carbonate on fine paper production. Iranian Journal of Wood and Paper Science Research, 30 (1): 14-25. (in Persian). https://doi: 10.22092/ijwpr.2015.8470.

4. Clausen, C. A.; Green, F.; Kartal, S. N., 2010: Weatherablity and leach resistance of wood impgregnated with nano-zinc oxide. Nanoscale Research Letters, 5 (9): 1464-1467. https://doi 10.1007/s11671-010-9662-6.

5. Gasht Roodkhani, A.; Ghasemian, A.; Saraeian, A. R.; Dehmarde Ghaleno, M.; Manzorolajdad, S. M., 2009: Study on the mechanical and optical properties of kraft liner paper produced from mixing of OCC and virgin hardwoods kraft pulp. Iranian Journal of Wood and Paper 
Science Research, 24 (2): 264-274 (in Persian). https:// doi: 10.22092/ijwpr.2009.117383.

6. Girones, J.; Pardini, G.; Vilasea, F.; Pelach, M. A.; Mutje, P., 2010: Recycling of paper mill sludge as filler/reinforcemeni in polypropylene compositesJournal of Polymers and the Environment, 18: 407-412. https://dx.doi.org/10.1007/s10924-010-0169-0.

7. Moo-Young, H. K.; Ochola, C., 1999: The future of paper industry waste management.department of civil and environmental engineering. In: Proceedings of the Middle Atlantic Regional Conference, pp. 81-99.

8. Ismail, S. H.; Bakar, A. A., 2004: The effect of paper sludge content and size on the properties of polypropylene (PP)-ethylene propylene diene terpolymer (EPDM) composites. Journal of Reinforced Plastics and Composites, 24 (2): 147-159. https://doi: 10.1177/0731684405042955.

9. Ismail, S. H.; Bakar, A. A., 2005: Effects of chemical modification of paper sludge filled polypropylene (PP) / ethylene propylene diene terpolymer (EPDM) composites. Journal of Reinforced Plastics and Composites, 25 (1): 43-58. https://doi: 10.1177/0731684406055454.

10. Krogerus, B.; Eriksson, L.; Sundberg, A.; Mosbye, J. E.; Ahlroth, A.; Ostland, I.; Sjöström, L., 2002: Fines in closed circuits. In: Proceedings of $7^{\text {th }}$ European Workshop on Lignocellulosic and Pulp (EWLP), Turku, Finland, pp. 435-438.

11. Lertsutthiwong, P.; Khunthon, S.; Siralertmukul, K.; Noomun, K.; Chandrkrachang, S., 2008: New insulating particleboards prepared from mixture of solid wastes from tissue paper manufacturing and corn peel. Bioresource Technology, 99: 4841-4845. https://doi:10.1016/j.biortech.2007.09.051.

12. Mehmood, K.; Rehman, S. K. U.; Wang, J.; Farooq, F.; Mahmood, Q.; Jadoon, A. M.; Javed, M. F.; Ahmad, I., 2019: Treatment of pulp and paper industrial effluent using physicochemical process for recycling. Water, 11 (11): ID 2393. https://doi: 10.3390/w11112393.

13. Miri, S. M.; Ghasemian, A.; Aryaie Monfared, M. H., 2016: Investigation of optical and mechanical properties of MOW Deinked Pulp by Neutral Deinking. Journal of Wood and Forest Science and Technology Research, 23 (4): 293-314 (in Persian).

https://doi: 10.22069/jwfst.2016.9539.1507.

14. Nazeri, A. M.; Talaeepoor, M.; Mirshokraie, S. A., 2008: The study of fiber fines and its effects on mechanical strength of newsprint paper from CMP pulp. Iranian Journal of Wood and Paper Science Research, 22 (2): 121-131 (in Persian). https://doi: 10.22092/ijwpr.2007.117419.

15. Neeru, C.; Chandrajit, B.; Vidyasagar, J., 2013: Biological production of xylitol from corn husk and switchgrass by Pichia Stiptis. Research Journal of Chemical Science, 3 (3): 58-64.

16. Pandey, J. K.; Lee, S.; Kim, H. J.; Tankagi, H.; Lee, C. S.; Ahn, S. H., 2012: Preparation and properties of cellulosebased nano composites of clay and polypropylene. Journal of Applied Polymer Science, 125 (1): 651-660. https://doi: 10.1002/app.34546.

17. Pappu, A.; Saxena, M.; Asolekar, S. R., 2007: Solid wastes generation in India and their recycling potential in building materials. Building and Environment, 42: 23112320. https://doi.org/10.1016/j.buildenv.2006.04.015.

18. Sabazoodkhiz, R.; Rahmaninia, M.; Ramezani, O., 2017: Interaction of chitosan biopolymer with silica nanoparticlesas a novel retention/drainage and reinforcement aid in recycled cellulosic fibers. Cellulose, 24 (1): 34333444. https://doi: 10.1007/s10570-017-1345-3.

19. Scott, W., 2007: Principles of Paper Properties, E. Afra ( $2^{\text {nd }}$ ed.). Aeej Publication, Tehran, Iran, pp. 338 (in Persian).

20. Smook, G., 1995: Handbook for Pulp \& Paper Technologies, S. A. Mirshokraiee ( $2^{\text {nd }}$ ed.). Payame Noor Publication, Tehran, Iran, pp. 501 (in Persian).

21. Son, J.; Yang, H. S.; Kim, H. J., 2004: Physico-mechanical properties of paper sludge-thermoplastic polymer composites. Journal of Thermoplastic Composite Materials, 17 (6): 509-522. https://doi: 10.1177/0892705704038471.

22. Son, J.; Kim, H.; Lee, P., 2001: Role of paper sludge particle size and extrusion temperature on performance of paper sludge-thermoplastic polymer composites. Journal of Applied Polymer Science, 82 (11): 2709-2718. https://doi: 10.1002/app.2123.

23. ***TAPPI T205 sp-12, 2015: Forming handsheets for physical tests of pulp. TAPPI Press, Atlanta, GA, USA.

24. ***TAPPI T403 om-10, 2015: Bursting strength of paper. TAPPI Press, Atlanta, GA, USA.

25. ***TAPPI T441 om-13, 2015: Water absorptiveness of sized (nonbibulous) paper and paperboard (Cobb test). TAPPI Press, Atlanta, GA, USA.

26. ***TAPPI T494 om-13, 2015: Tensile properties of paper and paperboard (using constant rate of elongation apparatus. TAPPI Press, Atlanta, GA, USA.

27. ***TAPPI T496 sp-13, 2015: Specimen preparation for cross directional internal tearing resistance for paper, paperboard and related materials. TAPPI Press, Atlanta, GA, USA.

28. ***TAPPI T818 cm-07, 2015: Ring crush of paperboard. TAPPI Press, Atlanta, GA, USA.

29. Tudarvari, Z.; Farsi, M.; Asadpur Atoei, G. H., 2016: Effect of fiber length variations of different OCC pulp recycled papers on strength properties of fluting paper. Journal of Wood and Forest Science Technology, 23 (4): 255-267 (in Persian). https://doi: 10.22069/jwfst.2016.9601.1511.

\section{Corresponding address:}

\section{Assoc. Prof. RAMIN VAYSI}

Islamic Azad University

Chalous Branch

Department of Wood and Paper Science and Technology

Chalous, IRAN

e-mail: vaysi_r452@yahoo.com 